JPH: Jurnal Pembaharuan Hukum

Volume 8, Number 3, December 2021

\title{
THE ROLE OF FORENSIC MEDICINE IN THE CRIMINAL EVIDENCE PROCESS
}

\author{
Setyo Trisnadi \\ Universitas Islam Sultan Agung, Semarang, Indonesia \\ trisnadisetyo@gmail.com
}

\begin{abstract}
Forensic Medicine has a very important role in disclosing a crime that has occurred, especially for cases that are difficult to solve or require special techniques to disclose. Its also very helpful for law enforcement officers to reveal a criminal act that occurs from the level of investigation to the stage of court against cases related to the human body or soul so as to make light of a criminal act that occurred. In cases related to injuries, health and life of a person caused by a crime, the doctor can explain as an expert witness in the settlement of criminal cases. In this study using a normative juridical method. The results obtained stated that the role of forensics in the examination of the judicial process was intended to determine the presence or absence of persecution, to determine whether or not there was a crime or a violation of decency, to determine the age of a person, to determine the certainty of a baby who died in the womb of a mother and examination at the scene. Cases are usually requested by the authorities, in the event that someone is found dead.
\end{abstract}

Keywords : Criminal; Evidence; Forensic; Medicine; Role.

\section{A. INTRODUCTION}

The judicial process begins with an investigation carried out by the police and culminates in the imposition of a crime and then ends with the execution of the sentence itself by the correctional institution. All these criminal processes are currently receiving a lot of attention from the public because of their performance, or the behavior of the officers who are far from good. ${ }^{1}$ The problem of violating the law or by other names, crime is the responsibility of every element of society, because in addition to crime as old as the history of people's lives, crime also develops from the embryo and construction of society itself. Van Bammelen once said that crime is any act that is immoral, violates norms, disrupts, and causes so much unrest in people's lives, so that people have the right to denounce, react, or express their rejection of the act. The community has the right to hate all forms of crime, because crime does not only contain unlawful acts, but also violates social, economic rights, and so on. ${ }^{2}$

Considering that crime is as old as human life, the level and variety of crime also follows the reality of the development of human life. The more

1 Eman Sulaiman, Problematika Penegakan Hukum Di Indonesia, Ash-Shahabah, Vol 2 No 1 2016, page 64-78

2 Abdul Wahid \& Mohammad Labib, Kejahatan Mayantara (Cyber Crime), Refika Aditama, Bandung, 2005, page. 6 
advanced and modern people's lives are, the more advanced and modern the types and modus operandi of crimes that occur in society will be. This seems to confirm an adage that "where there is society, there is crime".

Crime is not only a juridical problem, but also a technical and human problem. Crime as a juridical problem is a human act that violates the provisions (regulations) of the applicable criminal law (positive law). As an act that violates the law, the knowledge used to deal with this problem is criminal law and criminal procedural law, so that both sciences are the pillars of the teacher or the main knowledge in solving crime cases without reducing the important role of the above sciences. ${ }^{3}$

Efforts made to seek the material truth of a criminal case are intended to avoid mistakes in imposing a criminal offense against a person, this is as stipulated in Article 6 paragraph (2) of Act No. 48 of 2009 concerning Judicial Power which states that: " No one can be sentenced to a crime, except if the court, because of the legal evidence according to the law, is convinced that a person who is considered to be responsible has been guilty of the act that has been charged against him.

With the provisions of the legislation above, in the process of resolving criminal cases, law enforcers are obliged to endeavor to collect evidence and facts regarding criminal cases that are handled as completely as possible. In an effort to obtain the evidence needed for the purpose of examining a criminal case, law enforcers are often faced with a problem or certain things that cannot be resolved by themselves because the problem is beyond their capabilities or expertise. In this case, the assistance of an expert is very important in order to find the material truth as completely as possible for the law enforcers.

According to the provisions of the criminal procedure law in Indonesia, requests for expert assistance are regulated and stated in Act No. 8 of 1981 concerning the Criminal Procedure Code (KUHAP). For requests for expert assistance at the investigation stage, it is stated in Article 120 paragraph (1) of the Criminal Procedure Code, while for requests for expert information assistance at the trial examination stage, it is contained in Article 180 paragraph (1) of the Criminal Procedure Code.

In an examination of a trial of a criminal case, a judge who conducts a trial examination without any evidence, the judge will not be able to know and understand whether a crime has occurred and whether the defendant has actually committed a crime and is responsible for a criminal event, so there is an evidence is absolutely necessary and must exist, if the court is faced with cases related to injuries, forensic doctors play a very important role in law enforcement to reveal evidence that can be in the form of a body or part of the human body. There are many examples of cases, for example in murder cases, rape cases, torture cases and even mutilation cases that require the role of a forensic doctor to assist law enforcement officers in

3 Musa Perdana Kusuma, Bab-bab Tentang Kedokteran Forensik, Ghalia Indonesia, Jakarta, 1989, page. 205,208. 
uncovering a crime according to their expertise and knowledge of how the crime was committed by the defendant by examining the victim. ${ }^{4}$

Forensic doctors also play an important role in finding material truth in criminal cases $^{5}$, the fields of law and medicine cannot be separated to enforce the law, especially in the context of proving someone's guilt related to the body or human body parts. Seeing the growing expertise of criminals who can hide their crimes before the law, so that more and more doctors are needed who have their own expertise in assisting the process of resolving cases related to the human body, only doctors are able and can help reveal the mystery of the state of evidence that can be found in the form of a body or part of the human body.

No single science can solve the problem that is its object without the help of other sciences, as well as the science of law. If the judiciary is faced with cases related to injuries to the human body, it is clear that everything related to injuries is not a study in the field of legal science. Not to mention, if these injuries have occurred for some time in the past, their present existence may have recovered or may have worsened. In this regard, to determine when the injury occurred and whether the injury in question was caused by a crime, evidence that can be legally accounted for is needed. ${ }^{6}$

Forensic medicine studies the use of medical science for the benefit of law enforcement and justice. The existence of a forensic doctor or a doctor who conducts an examination of a victim of a crime, or a suspected perpetrator of a crime, is an absolute thing and cannot be ignored because an investigation process must be carried out and supported by science (scientific investigation). ${ }^{7}$

In cases related to injuries, health and life of a person caused by a crime, the doctor can explain as an expert witness in the settlement of criminal cases. It is still fortunate for law enforcement, because almost every crime leaves trace evidence, which if analyzed scientifically is not impossible to make light of the criminal case. Because law enforcers are not equipped and it is also impossible to be equipped with all kinds of knowledge and skills that can be used to scientifically analyze all types of evidence that have been found, expert assistance is needed. In the event that the evidence is in the form of a corpse, a living person, a part of a human body, or something derived from a human body, the appropriate expert is a doctor. The reason is because doctors have knowledge of anatomy,

4 Yulia Monita, Dheny Wahyudhi, Peranan Dokter Forensik dalam Pembuktian Perkara Pidana, Inovatif, Vol. 6 No. 7, 2013, page 127-141

5 Ong Argo Victoria \& Myska. (2021). Doctor's Constributions in Transportation Monitoring During COVID-19 Pandemic, KnE Social Sciences, Dubai-Uni Emirates Arab (UEA),Vol.5 No.1, 598-618

6 Waluyadi, IImu Kedokteran Kehakiman Dalam Perspektif Peradilan \& Aspek Hukum Praktik Kedokteran, Djambatan, Jakarta, 2007, page 1.

7 Abdul Mun'im Idries, Pedoman Praktis IImu Kedokteran Forensik Bagi Praktisi Hukum, Sagung Seto, Jakarta, 2009, page $1 \& 5$. 
physiology, biochemistry, pathology, psychiatry in addition to being able to carry out various kinds of forensic examinations. ${ }^{8}$

It is the lack of knowledge possessed by law enforcers, which makes investigators have to cooperate with other parties, who are more skilled and know the intricacies of the object being handled by law enforcers. Thus, in the event that an examination for the benefit of the judiciary handles a victim, whether injured, poisoned, or died, which is suspected to be due to an incident which constitutes a criminal act, the investigator is authorized to submit a request for expert testimony, which includes expert testimony here, namely a judicial medical expert or a doctor or other expert in order to assist the investigation process. ${ }^{9}$

The role of doctors is very important here, namely in terms of doctors as expert witnesses. In the day-to-day duty of doctors, in order to assist law enforcement officers, the most work that must be done is to examine and if necessary treat people who have experienced violence, in addition to examining corpses and conducting autopsies. Items examined by a doctor, whether living people, corpses, body organs, or objects obtained from inside the body, are evidence. Its position is no different from other evidence obtained from the scene or other places confiscated by investigators. Here, people who suffer from wounds, corpses, organs, or other objects obtained from the body are goods or objects that have a direct relationship with the crime. ${ }^{10}$

What is meant by medical discipline is compliance with applying the rules/provisions for the application of medical science in the implementation of medical services. Compliance with applying the rules of medical management (medical care) includes, among others, establishing a diagnosis, taking treatment actions, and establishing a prognosis. This is done by using indicators that meet the standards. These indicators include competency standards, service standards, ethical behavior standards, medical care standards, and clinical standards. The concreteness of doctors in carrying out medical practice must be carried out in accordance with service standards, professional standards and standard operating procedures. $^{11}$

Regarding the assistance of expert information needed in the process of examining a criminal case, this assistance at the investigation stage has a fairly important role to help investigators seek and collect evidence in their efforts to find the material truth of a criminal case. In certain cases, investigators even rely heavily on expert testimony to further reveal a criminal event that is being handled. Criminal cases are not only murder, but also torture and rape are examples of cases where investigators need the assistance of experts such as forensic doctors or other specialists to provide

8 Sofwan Dahlan, Ilmu Kedokteran Forensik Pedoman Bagi Dokter \& Penegak Hukum, Badan Penerbit Universitas Diponegoro, Semarang, 2002, page 17.

9 Ibid.

10 I Ketut Murtika \& Djoko Prakoso, Dasar-dasar Ilmu Kedokteran Kehakiman, Rineka Cipta, Jakarta, 1992, page 116.

11 Setyo Trisnadi, Perlindungan Hukum Profesi Dokter Dalam Penyelesaian Sengketa Medis, Jurnal Pembaharuan Hukum, Volume IV No. 1 January-April 2017, page 24-40 
medical information about the condition of the victim which in turn is quite influential for investigators' actions in revealing further. the case.

Forensic evidence in all developed countries has developed and is used as the main legal tool in giving judges conviction, even though the suspect/defendant is silent or silent or does not admit his actions. The role of the Forensic Laboratory is very useful in disclosing criminal cases committed by perpetrators, especially in narcotics crimes which are increasingly varied and contain various substances used, in this case the forensic laboratory examines the types of narcotics used, because of the many new types of narcotics. that are not known to the public in general, during examinations in forensic laboratories so that later it can be known what content is in the narcotics so that in court later when the judge will impose a sentence, it can be guided by the main evidence, namely evidence from the results of examinations in the forensic laboratory, in the process of material evidence later in court if the defendant does not admit his actions. ${ }^{12}$

The purpose of this paper is to find out and analyze the role of medical science in the examination of crimes, especially for the examination of crimes against life so that it is hoped that it can help law enforcement officers to uncover a criminal act that occurred, the fields of law and medicine cannot be separated in order to prove someone's guilt. This is based on the fact that not all knowledge is controlled by the judge, in this case a doctor is able and can help reveal the mystery of the condition of the evidence which can be a body or part of a human body, in a trial the judge who conducts a trial examines the evidence without paying attention to the evidence. With the evidence presented, the judge will not be able to know and understand whether a criminal act has occurred and whether the defendant who is brought before the trial has actually committed the crime and can be held responsible for the incident.

\section{B. RESEARCH METHODS}

Legal research is a process to find the rule of law, legal principles, and legal doctrines in order to answer the legal issues faced. Legal research is conducted to find solutions to legal issues that arise. Therefore, legal research is a research within the framework of know-how in law. The results achieved are to provide prescriptions in solving the problems at hand. ${ }^{13}$ In conducting a research to achieve goals, generally an accurate and directed method is needed, so that the objectives can be achieved completely and thoroughly, as well as to obtain and collect data in the research, an appropriate methodology is needed, so that what you want to achieve in this research is needed in a research can be justified the truth. ${ }^{14}$ The approach used in this research is normative juridical, meaning that this legal research

12 Andi Sofyan \& Abd.Asis, Hukum Acara Pidana Suatu Pengantar, Penerbit Kencana Prenamedia Group, Jakarta, 2014, page 8

13 Peter Mahmud Marzuki, Penelitian Hukum, Kencana Prenada Media Group, Jakarta, 2009, page 35

14 Ronny Hanitiyo Soemitro, Metodologi Penelitian Hukum, Ghalia Indonesia, Bandung, 1982, page 137-142. 
is carried out by examining library materials or secondary data, which in this case relates to the role of forensics in crime investigations.

\section{RESULTS AND DISCUSSION}

\section{The Role of Forensic Medicine in the Criminal Evidence Process}

Forensic medicine is a specialized branch of medical science that utilizes medical science for the benefit of law enforcement. The process of law enforcement and justice is a scientific endeavor, and not just common sense, non-scientific. Thus, in the enforcement of justice concerning the body, health and life of humans, the assistance of doctors with their knowledge of forensic medicine and medicolegal is very much needed.

Forensic medicine is defined as the study of the application of medical science for the benefit of the judiciary. according to prof. Sutomo Tjokronegoro defines that what is meant by judicial medicine is the use of medical science for the benefit of the court. This means that judicial medical science plays a very important role in assisting the police, prosecutors, and judiciary, in all matters that can only be solved by judicial medicine. According to Klotter-Meier, the definition of forensics is "Criminal laboratories are so important because not all defendants admit to their actions. Therefore, the evidence is carried out using experts working in the criminal laboratory world. As with experts in other fields, expertise in a criminal laboratory after attending special education, then training and experience. ${ }^{15}$

According to Prof. Sutomo Tjokronegoro Judicial Medicine is the use of medical science for the benefit of the court. ${ }^{16}$ This means that judicial medical science plays a very important role in assisting the police, prosecutors, and judiciary, in all matters that can only be solved by judicial medicine.

Another term of judicial medical science is Forensic Medicine, which is a translation of Gerechtelick geneeskunde or forensic medicine (legal medicine, or medical jurisprudence) which is a special branch of medicine that deals with the interaction between medicine and law. There are 2 branches; clinic forensic medicine which deals with living humans and from clinical pathology which deals with corpses. ${ }^{17}$

Forensic (derived from the Greek 'Forensis' which means debate or debate), is a field of science that is used to assist the process of upholding justice through the process of applying science (science). The forensic sciences group includes forensic physics, forensic chemistry, forensic psychology, forensic medicine, forensic toxicology, forensic computers, forensic ballistics, and forensic metallurgy. ${ }^{18}$

15 G.W Bawengan, Penyelidikan Perkara Pidana \& Teknik Inetroasi, Penerbit Pradnya Paramita, Jakarta, 1989, page 137.

16 Waluyadi, Op.Cit, page 1.

17 Ibid.

18 Andi Rachmad, Peranan Laboratorium Forensik Dalam Mengungkap Tindak Pidana Pada Tingkat Penyidikan, Samudra Keadilan, Vol 14, No 1, January-June 2019, page 15-24 
Forensic medical science, also known as judicial medicine, is one of the mandatory subjects in a series of medical education in Indonesia, where the legislation requires every doctor, both doctors, forensic medical specialists, clinical specialists to assist in carrying out forensic medical examinations for the benefit of the judiciary when requested. by the investigating police as regulated in Article 133 of the Criminal Procedure Code concerning the authority of investigators to submit requests for expert information to judicial medical experts where in cases related to violence against the body special expertise from forensic science doctors is needed as an investigative tool. Expert testimony given by a forensic medical expert is called expert testimony, while information given by a doctor who is not a forensic medical expert is called a statement. ${ }^{19}$

Forensic Medicine plays a role in determining the causal relationship between an action and the consequences that will result from the action, whether it causes injury to the body, or causes health problems, or causes the death of a person, where these consequences should be presumed to have occurred a crime occurred. Given its very prominent role among the existing forensic sciences in terms of assisting the judicial process, forensic medicine is often called "the mother of forensic science".

Forensic doctors or so-called forensic experts provide examination results, which then from the results of the examination can be known about whether a person is not healthy, or the person's death was caused by a criminal act or not. The forensics role can provide assistance in relation to the judicial process in matters of: ${ }^{20}$

a. Examination of injured victims by forensic experts is intended to identify :

1) Whether there is persecution or not;

2) Determine whether or not there is a crime or violation of decency;

3) To find out someone's age;

4) To determine the certainty of a baby who dies in the womb of a mother. All of these will be used as the basis for determining whether or not there is a violation of Articles 352, 351, 285, 292, $341,342,288$, and 44 of the Criminal Code.

b. Examination at the crime scene (TKP). Usually requested by the authorities, in the event that someone is found dead.

1) Post-mortem examination, in this case examination by a forensic expert, is intended to determine whether a person who has become a corpse died naturally or otherwise, or there is also a possibility that there has been previous persecution that led to the death of that person. To determine the cause of death, the forensic doctor must autopsy (dissect) the corpse.

2) Examination of victims who have been buried is not only possible

19 Koesparmono Irsan, Kedokteran Forensik, Universitas Pembangunan "Veteran", Jakarta, 2008, page 9.

20 Abdul Mun 'im Idries. Op.Cit, page 54. 
for victims of crimes, which to eliminate their traces, the perpetrators bury them secretly. The judge can ask for a Visum et repertum of the buried corpse, for the purpose of examination at a court hearing.

3) Examination of evidence, in this case the evidence in question is evidence which, when seen with the naked eye, is difficult to prove who actually owns the goods. Example: Blood, sperm, fingerprints.

4) Giving testimony in court in this regard what is said by the forensic expert will be categorized as expert testimony.

The evidence obtained at the forensic medical examination is indirect (circumstantial) evidence resulting from a criminal act. Forensic medical examination in accordance with correct and accurate procedures, will help enforce the law. ${ }^{21}$

The role of Forensic Medicine in the process of proving criminal cases is strengthened by the sound of Article 133 paragraph (1) of the Criminal Procedure Code which contains the following: "In the case of an investigator for the sake of justice regarding a victim, whether injured, poisoned or dead, which is suspected to be due to an incident which is a criminal act, he is authorized to submit requests for expert information to a judicial medical expert or a doctor and/or other expert. Justice and independence often depend on a trustworthy forensic laboratory. Analytical errors can mean freedom for the guilty and detention for the innocent. Forensic labs can repair and order regulatory systems that will bring about improvements. ${ }^{22}$

Forensic medicine is becoming increasingly important for the judicial process to obtain justice. In cases of persecution, usually not all victims die, but there are also living victims. Apart from being a victim of abuse, the victim also acts as a patient, namely as a human being who is a legal subject with all the demands of his rights and obligations. This means that a living victim is not completely evidence, but is copied into the form of Visum et repertum according to its definition, so visum et repertun is very useful in proving a case based on procedural law. The examination of a criminal case in a judicial process is essentially aimed at finding the material truth of the case. This can be seen from the various efforts made by law enforcement officers in obtaining valid evidence to uncover a case at the examination stage. ${ }^{23}$

Forensic science is very helpful for law enforcement officers to reveal a criminal act that occurs from the level of investigation to the stage of court against cases related to the human body or soul so as to

21 Sugiharto FA. Praktek Forensik Berbasis Bukti: Menghubungkan Bukti Sirkumtansial dengan Pendapat Ahli, Prosiding Konas PDFI, 2016, page 134.

22 Amelia Kalangit, J. Mallo, D. Tomuka, Peran Ilmu Kedokteran Forensik Dalam Pembuktian Tindak Pidana Pemerkosaan Sebagai Kejahatan Kekerasan Seksual, E-Clinic, Vol 1, No 1 2013, page $1-11$

23 Onan Purba, Rumelda Silalahi, Peran Ilmu Kedoteran Forensik Dalam Pembuktian Tindak Pidana Penganiayaan, Jurnal Retenrum, Volume.1 No. 02 August 2020, page 127-133 
make light of a criminal act that occurred. In general, the usual forensic stages include collection (acquisition), protection (preservation), analysis (analysis) and presentation (presentation).

The contribution of Forensic Medicine in assisting the completion of the process of investigating criminal cases involving human life is stated in the form of Visum et repertum. Visum et repertum is a substitute for evidence in Article 184 of the Criminal Code which is classified as documentary evidence. This Visum et repertum can only be made if the police (investigators) directly submit a Request for Visum et repertum, as has been stated in Article 133 of the Criminal Procedure Code (1) In the event that an investigator for the purposes of the judiciary handles a victim, whether injured, poisoned or dead, it is suspected because the event is a criminal act, he is authorized to submit a request for information from a judicial medical expert or a doctor or other expert. (2) Requests for expert information as referred to in paragraph (1) shall be made in writing, which is stated in the letter explicitly for wound examination or post-mortem examination and or post-mortem examination. ${ }^{24}$

\section{CONCLUSION}

the role of forensics in the examination of the judicial process was intended to determine the presence or absence of persecution, to determine whether or not there was a crime or a violation of decency, to determine the age of a person, to determine the certainty of a baby who died in the womb of a mother and examination at the scene. Cases are usually requested by the authorities, in the event that someone is found dead. In proving criminal cases related to the human body or soul, forensic doctors have a very important role to assist judges in uncovering criminal events, for that there must be strict provisions governing the position of doctors as expert witnesses, then judges must also be wise in assessing tools. The evidence submitted by the doctor is either in writing orally, so it is hoped that the material truth can be realized. Besides that, coordination between law enforcement officers and doctors must be improved, especially for crimes related to the human body or soul.

\section{BLIBIOGRAPHY}

\section{Books :}

Abdul Mun'im Idries, 2009, Pedoman Praktis IImu Kedokteran Forensik Bagi Praktisi Hukum. Jakarta;

Abdul Wahid \& Mohammad Labib, 2005, Kejahatan Mayantara (Cyber Crime), Refika Aditama, Bandung;

24 Soerodibroto S, KUHP \& KUHAP Dilengkapi Yurisprudensi Mahkamah Agung \& Hoge Raad, edisi keempat, cetakan ketujuh, RajaGrafindo Persada, Jakarta, 2002, page 23 
Andi Sofyan \& Abd.Asis, 2014, Hukum Acara Pidana Suatu Pengantar, Penerbit Kencana Prenamedia Group, Jakarta;

Idries A.M., 2009, Pedoman Praktis IImu Kedokteran Forensik Bagi Praktisi Hukum, Sagung Seto, Jakarta;

G.W Bawengan, 1989, Penyelidikan Perkara Pidana \& Teknik Inetroasi, Penerbit Pradnya Paramita, Jakarta;

I Ketut Murtika \& Djoko Prakoso, 1992, Dasar-dasar IImu Kedokteran Kehakiman, Rineka Cipta, Jakarta;

Koesparmono Irsan, 2008, Kedokteran Forensik, Universitas Pembangunan "Veteran", Jakarta;

Musa Perdana Kusuma, 1989, Bab-bab Tentang Kedokteran Forensik, Ghalia Indonesia, Jakarta;

Peter Mahmud Marzuki, 2009, Penelitian Hukum, Kencana Prenada Media Group, Jakarta;

Ronny Hanitiyo Soemitro, 1982, Metodologi Penelitian Hukum, Ghalia Indonesia, Bandung;

Soerodibroto S, 2002, KUHP \& KUHAP Dilengkapi Yurisprudensi Mahkamah Agung \& Hoge Raad, edisi keempat, cetakan ketujuh, RajaGrafindo Persada, Jakarta;

Sofwan Dahlan, 2002, IImu Kedokteran Forensik Pedoman Bagi Dokter \& Penegak Hukum, Badan Penerbit Universitas Diponegoro, Semarang;

Waluyadi, 2007, IImu Kedokteran Kehakiman Dalam Perspektif Peradilan \& Aspek Hukum Praktik Kedokteran, Djambatan, Jakarta;

\section{Journals :}

Amelia Kalangit, J. Mallo, D. Tomuka, Peran Ilmu Kedokteran Forensik Dalam Pembuktian Tindak Pidana Pemerkosaan Sebagai Kejahatan Kekerasan Seksual, E-Clinic, Vol 1, No 1, 2013;

Andi Rachmad, Peranan Laboratorium Forensik Dalam Mengungkap Tindak Pidana Pada Tingkat Penyidikan, Samudra Keadilan, Vol 14, Nomor 1, January-June 2019;

Eman Sulaiman, Problematika Penegakan Hukum Di Indonesia, Ash-Shahabah, Vol 2 No 1, 2016;

Onan Purba, Rumelda Silalahi, Peran Ilmu Kedoteran Forensik Dalam Pembuktian Tindak Pidana Penganiayaan, Jurnal Retenrum, Volume.1 No. 02 August 2020;

Ong Argo Victoria \& Myska, Doctor's Constributions in Transportation Monitoring During COVID-19 Pandemic, KnE Social Sciences, Dubai-Uni Emirates Arab (UEA), Vol 5 No 1 2021; 
Setyo Trisnadi, Perlindungan Hukum Profesi Dokter Dalam Penyelesaian Sengketa Medis, Jurnal Pembaharuan Hukum, Volume IV No. 1 January-April 2017;

Sugiharto FA. Praktek Forensik Berbasis Bukti: Menghubungkan Bukti Sirkumtansial dengan Pendapat Ahli. Prosiding Konas PDFI, 2016;

Yulia Monita, Dheny Wahyudhi, Peranan Dokter Forensik dalam Pembuktian Perkara Pidana, Inovatif, Vol. 6 No. 7, 2013. 